\title{
THE CHOLINE-ESTERASE ACTIVITY OF THE BLOOD SERUM IN DISEASE
}

\author{
By A. T. MILHORAT \\ (From the New York Hospital and Departments of Medicine and Pharmacology, Cornell Uni- \\ versity Medical College, and the Russell Sage Institute of Pathology, New York City)
}

(Received for publication May 9, 1938)

The investigations of Dale and his coworkers $(1,2)$ on the chemical transmission of parasympathetic nerve stimulation and of Walker $(3,4)$ on the use of physostigmine and prostigmin in myasthenia gravis have stimulated interest in the choline-esterase activity of serum. Lucas, Hall, and Ettinger (5) studied the serum esterase activity of 200 subjects and obtained results that were in essential agreement with the earlier findings of Stedman, Stedman, and Easson (6) and the more recent ones of McGeorge (7) on 132 patients. Although wide variations occurred among the subjects, the esterase activity was found to be constant over periods of many weeks, and no correlation with any type of clinical syndrome could be found. However, in myasthenia gravis conflicting findings have been reported. Thus, Hicks (8) found in one patient an abnormally high esterase activity which increased even further during exacerbations of the muscular symptoms. Stedman and Russell (9), on the other hand, observed serum esterase values in myasthenia gravis that were lower than in the other clinical conditions they studied, and believed that the distribution of the enzyme between the corpuscles and the serum was different from that in other conditions.

In the present investigations the choline-esterase of the sera of 109 subjects was determined. The clinical syndromes studied included a wide variety of conditions. Some of the subjects were without organic disease; many were only moderately ill, and others were in the advanced or even final stages of disease. In many instances the serum esterase activity was studied at frequent intervals over periods of several months. The effect of many factors was investigated. These included the age, sex, body weight, and total muscular mass of the subjects, changes in the clinical status, convulsions, fasting, and changes in the concentration of the constituents of the blood such as the protein, hemoglobin, and red blood cells. Six of the patients had myasthenia gravis. Of these, three were in a special research ward for periods of several months where esterase determination's were made practically every day, and often several times on the same day.

\section{METHODS}

The method employed for the determination of the choline-esterase activity of the serum was McGeorge's modification (7) of the procedure of Stedman, Stedman, and White (10). The method utilizes the amount of acid liberated in the hydrolysis of acetylcholine by the serum as an index of the activity of the choline-esterase. The serum was added to a substrate of acetylcholine bromide in a rubber stoppered flask which was kept suspended in a water bath at $30^{\circ} \mathrm{C}$. The acid set free by the enzyme was neutralized by continuous titration with alkali which was added from a microburette by means of an intravenous needle which pierced the rubber stopper in the flask. The number of cubic centimeters of $1 / 100 \mathrm{~N} \mathrm{NaOH}$ needed to keep the $\mathrm{pH}$ of the solution at 8.0 during the period of 20 minutes is the unit used in this report for expressing the choline-esterase activity. All determinations were made in duplicate. In each instance simultaneous determinations of the spontaneous cleavage of duplicate samples of acetylcholine substrate were made. The results of these determinations are at variance with those of McGeorge who obtained such constant values that he later dispensed with the blank determinations and assumed a constant and small figure. In these studies the results obtained were invariably higher than those assumed by McGeorge. Furthermore, they varied not only with different samples of acetylcholine but often with specimens removed from the same bottle. Antopol, Tuchman, and Schifrin (11) likewise found that the spontaneous hydrolysis of the acetylcholine varied even when the samples were obtained from the same bottle.

\section{OBSERVATIONS}

The data on the choline-esterase activity of the sera of 109 subjects are given in Table I. About 24 per cent of the subjects had serum esterase values of between 2.0 and 2.5 , and an almost like number had values of between 2.5 and 3.0. In about 18 per cent of the patients the esterase 
TABLE I

The serum choline-esterase activity of 109 patients

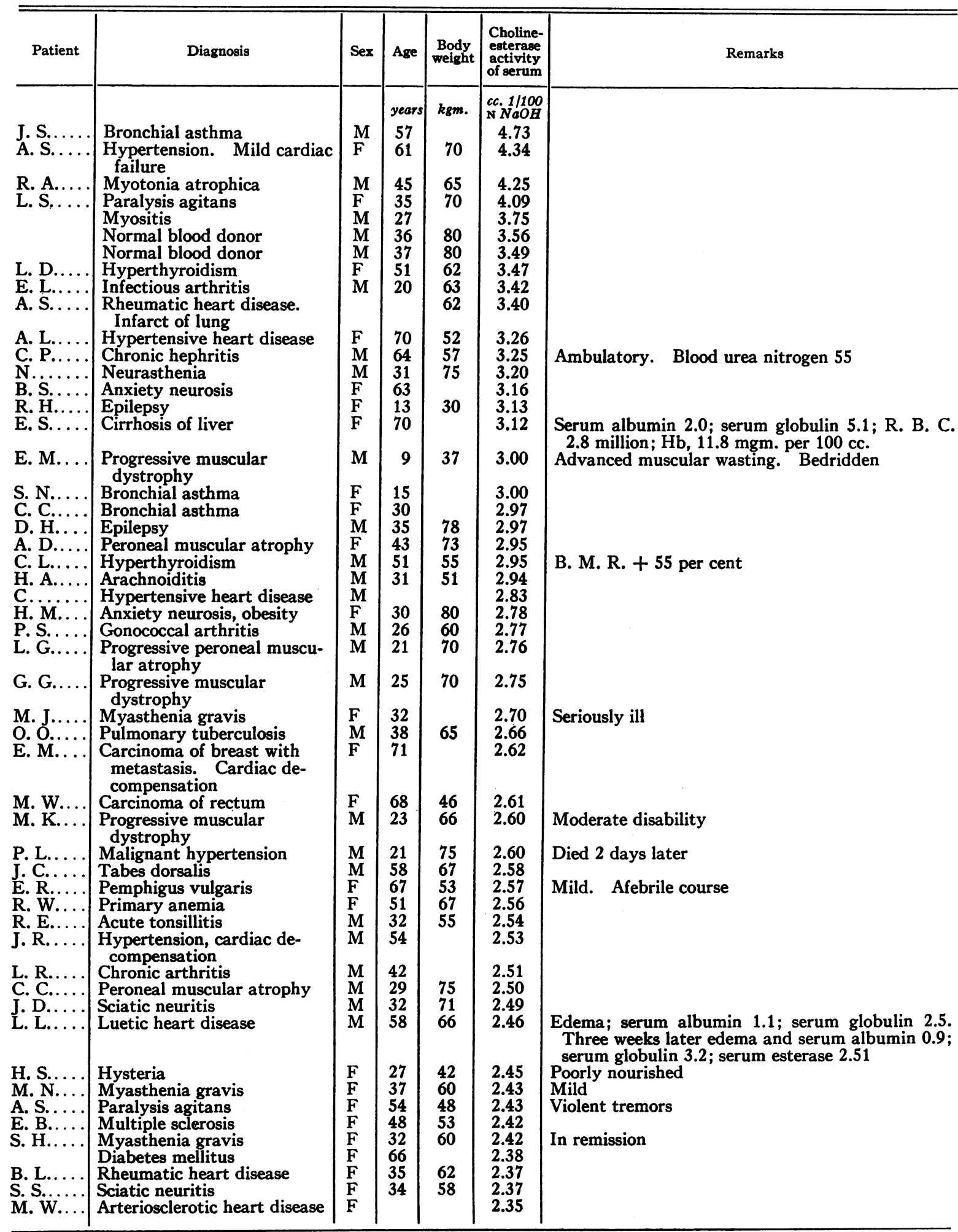


TABLE I-Continued

\begin{tabular}{|c|c|c|c|c|c|c|}
\hline Patient & Diagnosis & Sex & Age & $\left|\begin{array}{c}\text { Body } \\
\text { weight }\end{array}\right|$ & $\begin{array}{l}\text { Choline- } \\
\text { esterase } \\
\text { activity } \\
\text { of serum }\end{array}$ & Remarks \\
\hline & & & years & $\mathrm{kgm}$. & $\begin{array}{l}\mathrm{cc} .1 / 100 \\
\mathrm{~N} \mathrm{NaOH}\end{array}$ & \\
\hline $\begin{array}{l}\text { J. R... } \\
\text { A. P... } \\
\text { M. R.. }\end{array}$ & $\begin{array}{l}\text { Myasthenia gravis } \\
\text { Hypertensive heart disease } \\
\text { Alopecia totalis }\end{array}$ & $\begin{array}{l}\mathrm{F} \\
\mathrm{F}\end{array}$ & $\begin{array}{l}21 \\
70 \\
33\end{array}$ & $\begin{array}{l}60 \\
56 \\
53\end{array}$ & $\begin{array}{l}2.34 \\
2.34 \\
2.34\end{array}$ & Severe \\
\hline & $\begin{array}{l}\text { Subacute combined sclerosis } \\
\text { Pulmonary tuberculosis }\end{array}$ & $\begin{array}{l}\mathbf{M} \\
\mathbf{M}\end{array}$ & $\begin{array}{l}61 \\
36\end{array}$ & $\begin{array}{l}56 \\
56\end{array}$ & $\begin{array}{l}2.33 \\
2.32\end{array}$ & Bedridden \\
\hline R. J.. & $\begin{array}{l}\text { Bronchial asthma } \\
\text { Myasthenia gravis }\end{array}$ & $\mathrm{M}$ & $\begin{array}{l}33 \\
33\end{array}$ & $\begin{array}{l}60 \\
65\end{array}$ & $\begin{array}{l}2.31 \\
2.30\end{array}$ & Severe \\
\hline $\begin{array}{l}\text { G. H..... } \\
\text { K. R.... }\end{array}$ & $\begin{array}{l}\text { Rheumatic fever } \\
\text { Bronchial asthma }\end{array}$ & F & $\begin{array}{l}28 \\
42\end{array}$ & 50 & $\begin{array}{l}2.29 \\
2.28\end{array}$ & \\
\hline $\begin{array}{l}\text { T. R...... } \\
\text { A. D...... }\end{array}$ & $\begin{array}{l}\text { Diabetes mellitus. Carbuncle } \\
\text { Gastric ulcer }\end{array}$ & M & 55 & 78 & $\begin{array}{l}2.26 \\
2.21\end{array}$ & \\
\hline A. M.... & $\begin{array}{l}\text { Epilepsy } \\
\text { Myasthenia gravis }\end{array}$ & F & $\begin{array}{l}18 \\
20\end{array}$ & $\begin{array}{l}48 \\
50\end{array}$ & $\begin{array}{l}2.20 \\
2.18\end{array}$ & $\begin{array}{l}\text { Frequent seizures } \\
\text { Moderate severity }\end{array}$ \\
\hline R. H...... & Gonococcal arthritis & $\mathbf{M}$ & $\begin{array}{l}39 \\
56\end{array}$ & $\begin{array}{l}65 \\
48\end{array}$ & 2.11 & \\
\hline $\begin{array}{l}\text { A. M..... } \\
\text { H. } Q . . . .\end{array}$ & $\begin{array}{l}\text { Hypertensive heart disease } \\
\text { Migraine }\end{array}$ & $\mathrm{F}$ & 54 & 48 & $\begin{array}{l}2.09 \\
1.97\end{array}$ & \\
\hline W. M.... & Cirrhosis of liver. Ascites & $M$ & 57 & 83 & 1.97 & \\
\hline W. K... & $\begin{array}{l}\text { Diabetes mellitus. Chole- } \\
\text { lithiasis }\end{array}$ & & 67 & 58 & 1.96 & \\
\hline $\begin{array}{l}\mathrm{J} . \mathrm{S} . \ldots . \\
\text { W. R..... } \\
\text { L.S..... }\end{array}$ & $\begin{array}{l}\text { Arteriosclerosis } \\
\text { Diabetes mellitus } \\
\text { Tumor of bladder }\end{array}$ & $\begin{array}{l}\mathbf{M} \\
\mathbf{M} \\
\mathbf{M}\end{array}$ & $\begin{array}{r}61 \\
25 \\
2\end{array}$ & $\begin{array}{l}50 \\
54\end{array}$ & $\begin{array}{l}1.96 \\
1.95 \\
1.89\end{array}$ & \\
\hline $\begin{array}{l}\text { C. M. } \\
\text { T. B. F.. }\end{array}$ & $\begin{array}{l}\text { Hyperthyroidism } \\
\text { Coronary thrombosis }\end{array}$ & $\mathrm{F}$ & $\begin{array}{l}28 \\
46\end{array}$ & $\begin{array}{l}53 \\
81\end{array}$ & $\begin{array}{l}1.86 \\
1.81\end{array}$ & Mild \\
\hline M. Y... & $\begin{array}{l}\text { Hypertension. Tumor of } \\
\text { spinal cord }\end{array}$ & $\mathrm{F}$ & 62 & 80 & 1.78 & \\
\hline $\begin{array}{l}\text { E. S.... } \\
\text { M. R... } \\
\text { J.W.... }\end{array}$ & $\begin{array}{l}\text { Infectious arthritis } \\
\text { Psychoneurosis } \\
\text { Subacute bacterial endo- } \\
\text { carditis }\end{array}$ & $\begin{array}{l}\mathbf{M} \\
\mathbf{F} \\
\mathbf{M}\end{array}$ & $\begin{array}{l}62 \\
36 \\
27\end{array}$ & 75 & $\begin{array}{l}1.77 \\
1.76 \\
1.75\end{array}$ & \\
\hline $\begin{array}{l}\text { C. M... } \\
\text { H. T.... }\end{array}$ & $\begin{array}{l}\text { Carcinoma of bronchus } \\
\text { Gastric ulcer, hemorrhage }\end{array}$ & $\begin{array}{l}\mathrm{M} \\
\mathrm{F}\end{array}$ & $\begin{array}{l}48 \\
37\end{array}$ & 55 & $\begin{array}{l}1.72 \\
1.68\end{array}$ & \\
\hline R. T.... & $\begin{array}{l}\text { Rheumatic heart disease. } \\
\text { Ascites }\end{array}$ & $\mathbf{M}$ & 35 & 75 & 1.63 & \\
\hline J. McK. & Gastric ulcer, hemorrhage & $\mathbf{M}$ & 41 & & 1.61 & $\begin{array}{l}\text { R. B. C. } 4.0 \text { million; Hb, } 11.2 \mathrm{mgm} \text {. per } 100 \text { cc. } \\
\text { Patient almost in shock. } 8 \text { days later patient } \\
\text { much improved; } R \text {. B. C. } 4.2 \text { million; Hb, } 11.5 \\
\text { mgm. per } 100 \text { cc., serum esterase } 2.13\end{array}$ \\
\hline $\begin{array}{l}\text { T. S... } \\
\text { A. W.. }\end{array}$ & $\begin{array}{l}\text { Diabetes mellitus } \\
\text { Rheumatic heart disease }\end{array}$ & $\begin{array}{l}\mathbf{M} \\
\mathbf{M}\end{array}$ & $\begin{array}{l}27 \\
26\end{array}$ & $\begin{array}{l}67 \\
54\end{array}$ & $\begin{array}{l}1.57 \\
1.56\end{array}$ & 2 weeks later much improved. Serum esterase 2.21 \\
\hline A. D... & Rheumatic heart disease & $\mathbf{M}$ & 34 & 64 & 1.55 & \\
\hline $\begin{array}{l}\text { W. H.... } \\
\text { V. O..... }\end{array}$ & $\begin{array}{l}\text { Rheumatic heart disease } \\
\text { Rheumatic heart disease }\end{array}$ & $\frac{\mathbf{M}}{\mathbf{F}}$ & $\begin{array}{l}29 \\
28\end{array}$ & $\begin{array}{l}45 \\
52\end{array}$ & $\begin{array}{l}1.55 \\
1.40\end{array}$ & \\
\hline $\begin{array}{l}\text { I. H..... } \\
\text { E. G.... }\end{array}$ & Undulant fever & F & $\begin{array}{l}28 \\
27 \\
52\end{array}$ & $\begin{array}{l}52 \\
55 \\
49\end{array}$ & $\begin{array}{l}1.40 \\
1.39\end{array}$ & Fever. Bedridden 2 months \\
\hline & $\begin{array}{l}\text { Carcinoma with metastases } \\
\text { and ascites }\end{array}$ & $\mathbf{M}$ & 45 & & 1.23 & \\
\hline A. $\mathbf{M}$. & Chronic nephrosis. Cachexia & $F$ & 45 & 48 & 1.20 & $\begin{array}{l}\text { R. B. C. } 2.6 \text { million; Hb, } 8.14 \text { mgm. per } 100 \mathrm{cc} \text {, } \\
\text { serum albumin } 2.5 \text {; serum globulin } 0.4\end{array}$ \\
\hline М.......... & $\begin{array}{l}\text { Chronic nephritis. Uremia } \\
\text { Diabetes mellitus }\end{array}$ & $\begin{array}{l}\mathbf{F} \\
\mathbf{M}\end{array}$ & $\begin{array}{l}24 \\
56\end{array}$ & 49 & $\begin{array}{l}1.20 \\
1.15\end{array}$ & 1 month later much improved. Serum esterase \\
\hline V. D. & $\begin{array}{l}\text { Carcinoma of bronchus with } \\
\text { metastases }\end{array}$ & $\mathbf{M}$ & 47 & 70 & 1.13 & \\
\hline G. C... & $\begin{array}{l}\text { Periarteritis nodosum } \\
\text { Chronic glomerular nephritis }\end{array}$ & $\begin{array}{l}\mathbf{M} \\
\mathbf{M}\end{array}$ & $\begin{array}{l}39 \\
57\end{array}$ & $\begin{array}{l}60 \\
86\end{array}$ & $\begin{array}{l}1.08 \\
1.05\end{array}$ & $\begin{array}{l}\text { Died } 1 \text { month later } \\
\text { Serum albumin } 2.7 \text {, serum globulin } 2.3, \text { R. B. C. } \\
4.1 \text { million; } H b, 12.3 \mathrm{mgm} \text {. per } 100 \mathrm{cc} \text {. }\end{array}$ \\
\hline V. A. & Cirrhosis of liver. Ascites & $\mathbf{M}$ & 48 & 69 & 1.02 & Serum albumin 2.1 ; serum globulin $3.2 ;$ R. B. C. \\
\hline J. $\mathbf{M}$. & $\begin{array}{l}\text { Chronic glomerular nephritis. } \\
\text { Uremia }\end{array}$ & $\mathbf{M}$ & 33 & 60 & 0.88 & $\begin{array}{l}\text { Blood urea nitrogen } 147 \text {; serum esterase } 0.66 \text { on day } \\
\text { before exitus }\end{array}$ \\
\hline T. K.. & $\begin{array}{l}\text { Pulmonary tuberculosis. } \\
\text { Cachexia }\end{array}$ & $\mathbf{M}$ & 47 & 60 & 0.80 & \\
\hline
\end{tabular}


TABLE I-Continued

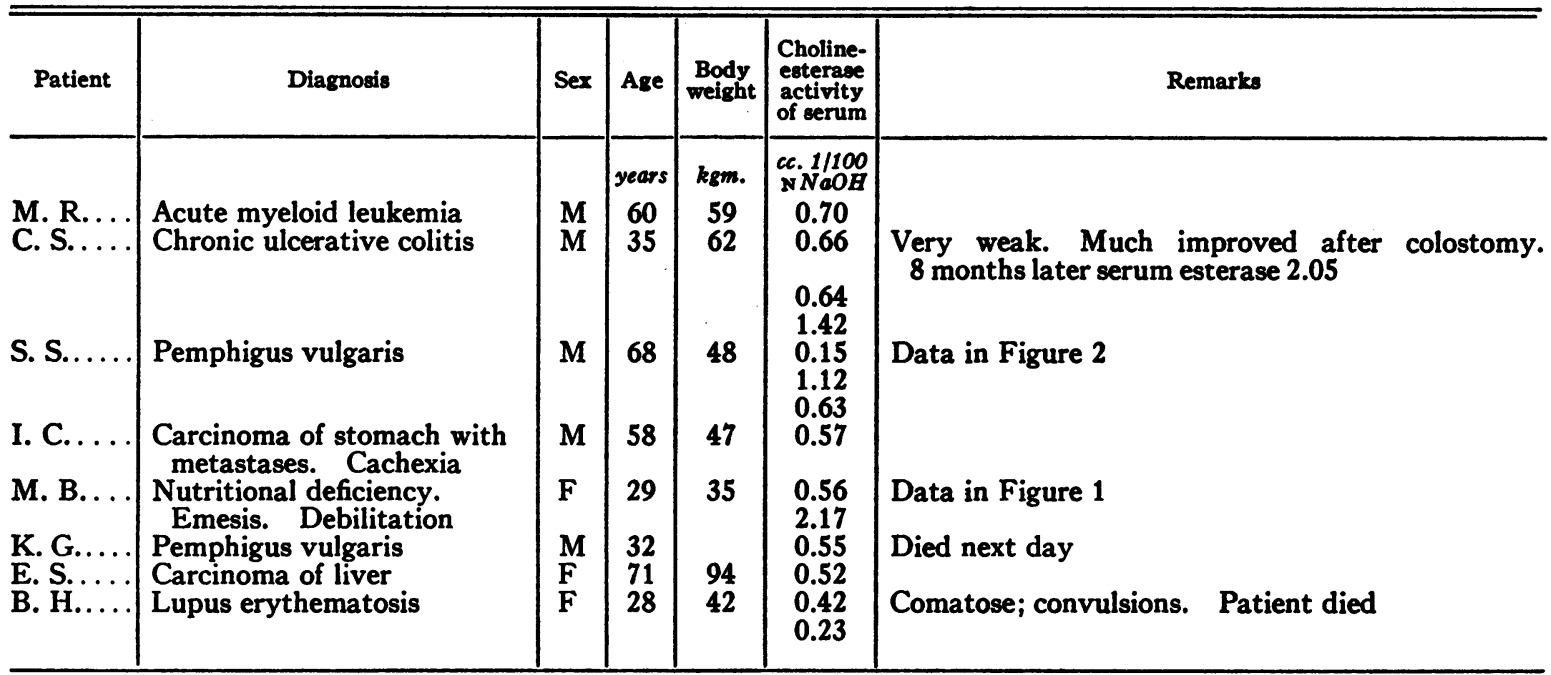

activity was between 1.5 and 2.0. Thus, 66 per cent of the subjects studied had esterase values that were between 1.5 and 3.0. Less than 4 per cent of the subjects studied had esterase values above 3.0. About 9 per cent had an esterase activity between 1.0 and 1.5 , and in about the same number the values were below 1.0. Special attention is given in this report to the subjects having low values.

A study of the data in Table I shows no correlation between the esterase activity of the serum and the type of clinical syndrome. The six patients with myasthenia gravis had esterase values of about the same order as other patients without myasthenia gravis. In Figure 1 are shown the serum esterase values of a patient with myasthenia gravis who was observed almost daily for a period of over 120 days. There was comparatively little change in the esterase activity during this period, although there were definite fluctuations in the patient's symptoms. Such minor changes as did occur in the esterase activity could not be correlated with the changes in muscular function.

The data in Table I show further that no correlation exists between the esterase activity of the serum and the age and sex of the subjects.

Total muscular mass. The total muscular mass

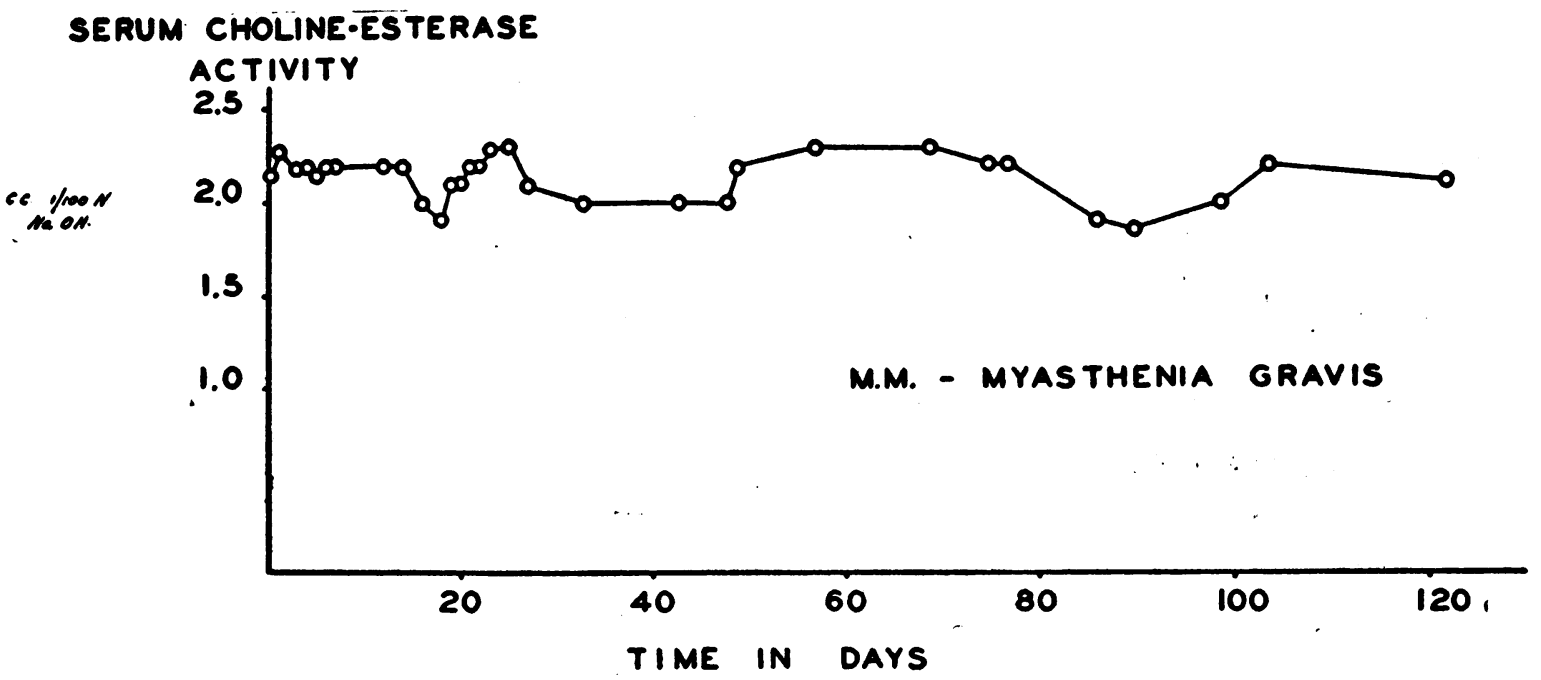

Fig. 1. Serum Choline-Esterase Activity of Patient M. M. with Myasteenia Gravis 
of 15 subjects was studied by determining their daily excretion of urinary creatinine. In normal subjects (12) and in patients with muscular wasting (13) the output of creatinine is a fairly good index of the total muscular mass of the body.

Three of the subjects (R.A., E.M., and L.G.) had extensive muscular wasting whereas Patient M. J. had severe impairment of muscular function but without obvious wasting of the muscles, and Patient A. C. had wasting which was restricted to a few muscle groups.

The data given in Table II show no relationship between the activity of the serum choline-

TABLE II

Lack of relationship between the serum choline-esterase activity and the metabolism of creatinine and creatine

\begin{tabular}{|c|c|c|c|c|c|}
\hline Patient & $\underset{\text { weight }}{\text { Body }}$ & Diagnosis & $\begin{array}{l}\text { Daily } \\
\text { urin- } \\
\text { ary } \\
\text { crea- } \\
\text { tinine* }\end{array}$ & $\begin{array}{l}\text { Daily } \\
\text { urin- } \\
\text { ary } \\
\text { crea- } \\
\text { tinet }\end{array}$ & $\begin{array}{c}\text { Serum } \\
\text { es- } \\
\text { terase } \\
\text { ac- } \\
\text { tivity }\end{array}$ \\
\hline & $\begin{array}{c}\text { kgm. } \\
70 \\
80 \\
70 \\
71 \\
70 \\
66\end{array}$ & $\begin{array}{l}\text { Peroneal muscular atrophy } \\
\text { Neurasthenia } \\
\text { Myasthenia gravis } \\
\text { Sciatic neuritis } \\
\text { Peroneal muscular atrophy } \\
\text { Progressive muscular }\end{array}$ & $\begin{array}{l}\text { grams } \\
1.860 \\
1.54 \\
1.504 \\
1.45 \\
1.40 \\
1.40\end{array}$ & $\begin{array}{l}\text { grams } \\
0 \\
0.046 \\
0.010 \\
0 \\
0.036 \\
0.010\end{array}$ & $\begin{array}{l}2.50 \\
3.20 \\
2.43 \\
2.49 \\
2.76 \\
2.70\end{array}$ \\
\hline $\begin{array}{l}\text { J. C..... } \\
\text { H. B. } \mathrm{F} . . \\
\text { C. M..... } \\
\text { J. R...... } \\
\text { M. J.... } \\
\text { M. M... } \\
\text { R. A.... } \\
\text { E. M.... }\end{array}$ & $\begin{array}{l}56 \\
55 \\
51 \\
55 \\
60 \\
60 \\
49 \\
53 \\
35\end{array}$ & $\begin{array}{l}\text { Pulmonary tuberculosis } \\
\text { Coronary thrombosis } \\
\text { Arachnoidits } \\
\text { Carcinoma of bronchus } \\
\text { Myasthenia gravis } \\
\text { Myasthenia gravis } \\
\text { Myasthenia gravis } \\
\text { Myotonia atrophica } \\
\text { Progressive muscular } \\
\text { dystrophy }\end{array}$ & $\begin{array}{l}1.28 \\
1.27 \\
1.27 \\
1.11 \\
1.07 \\
0.900 \\
0.850 \\
0.715 \\
0.200\end{array}$ & $\begin{array}{l}0 \\
0 \\
0 \\
0 \\
0.034 \\
0.180 \\
0.095 \\
0.062 \\
0.400\end{array}$ & $\begin{array}{l}2.32 \\
1.81 \\
2.94 \\
1.72 \\
2.34 \\
2.70 \\
2.18 \\
4.25 \\
3.00\end{array}$ \\
\hline
\end{tabular}

* Preformed creatinine.

$\dagger$ Creatine, expressed as creatinine.

esterase and the metabolism of creatinine or creatine. Patient E. M., with considerable muscular wasting, had an esterase value of 3.00. The output of creatinine was only 0.200 gram daily. Patient L. S., with normal muscular development and an output of creatinine of 1.54 grams, which was over seven times that of Patient E. M., also had an esterase level of about 3.0.

Debilitation. In this study all of the patients who had serum choline-esterase values of below 1.0 showed some degree of debilitation. The low activity of choline-esterase was not typical of any clinical syndrome, nor of any known pathological or chemical alteration. However, all these patients were so weak as to be bedridden. Those with the lowest esterase activity, e.g. Patients S. S., B. H., and K. G., whose esterase values were $0.63,0.23,0.55$ respectively, were extremely weak and either disoriented mentally or comatose. Patient B. H. had frequent convulsions of unexplained origin. Patient $T$. $K$. with chronic pulmonary tuberculosis and cachexia, and whose serum esterase had an activity of only 0.55 showed a phenomenon often seen in patients with " myotonia." When the belly of a voluntary muscle was struck with a percussion hammer a contraction appeared at the site of the blow and disappeared slowly over a period of about six seconds. On the other hand, none of the other patients in this group had any other symptoms that could be considered as being of a nature similar to that seen after excessive stimulation of the cholinergic nerves.

Five of the patients in this group died. Three of these patients showed a progressive lowering of the esterase activity up to the time of death. On the other hand, three of the patients had periods of clinical improvement and showed an increase in the serum esterase values during the periods when the clinical condition improved. The data on two patients who showed considerable change in their clinical status are summarized in Figures 3 and 4. Patient M. B. (Figure 2) had had frequent vomiting daily for a period of two years. She was emaciated, weak, and had skin lesions which resembled those seen in pellagra. On a régime of frequent small feedings of high caloric and vitamin content the patient improved rapidly and steadily. Emesis ceased, the skin lesions disappeared, and the patient's weight and strength increased so that on the forty-third day of treatment when she was discharged from the hospital her condition was considered to have returned to normal. The activity of the serum choline-esterase increased steadily as the patient's condition improved. At the time the patient left the hospital the serum esterase activity had increased from the low value of 0.56 to a level seen often in normal subjects, namely, 2.17.

Patient S. S. had pemphigus vulgaris with periods of serious exacerbation of symptoms and periods during which the symptoms subsided. At the time of the first determination of the serum esterase activity, the patient was markedly debilitated and was mentally disoriented. The esterase value at that time was 0.63 . During a period of clinical improvement when the patient was able to 


\section{CHOLINE-ESTERASE}

ACTIVITY

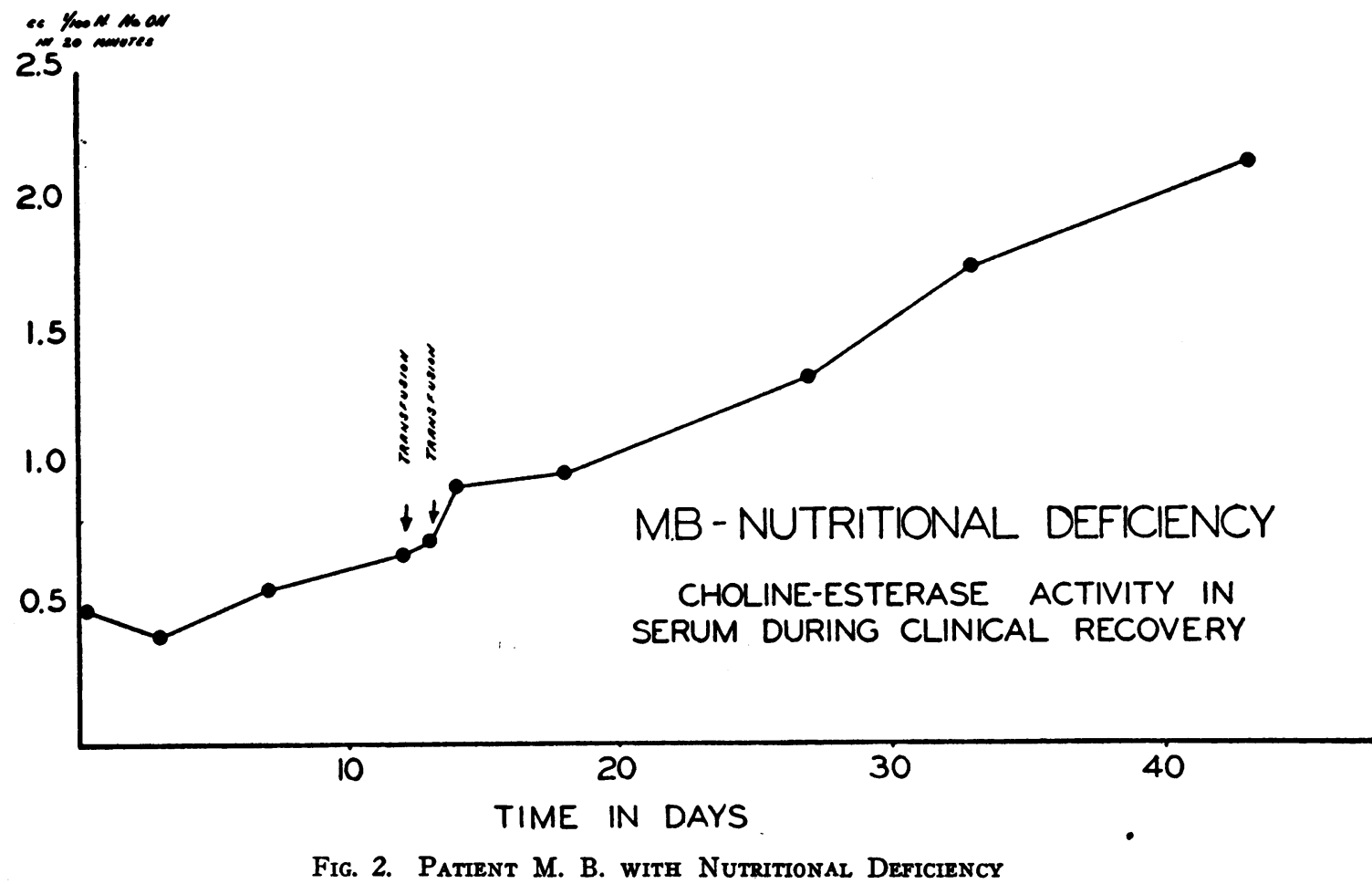

The esterase activity of the serum increased steadily as the patient's clinical condition improved.

walk about the ward the esterase value was 1.42 . During one period of exacerbation of symptoms when the patient was so seriously ill that his exitus was considered to be imminent the serum esterase activity was only 0.15 . After considerable fluctuation in the clinical condition the patient finally died. The esterase activity changed concomittantly with the fluctuations in the clinical condition of the patient. During the last exacerbation of the symptoms the serum esterase value fell rapidly. On the day before the patient died, the esterase activity of the serum was 0.63 .

Patient C. S. with chronic ulcerative colitis and severe debilitation had an esterase value of 0.66 . Following a colostomy the patient showed a gradual and remarkable improvement in his general condition and the serum esterase activity increased to 2.05 .

Determinations of several constituents of the blood such as the red blood cells, hemoglobin, and serum proteins reveal no correlation between the concentration of these substances in the blood and the serum esterase activity. Thus, in several patients wide changes in the concentration of these substances were not accompanied by any change in the serum esterase activity. Furthermore, changes in the esterase activity in other subjects occurred without any consistent alteration in the amounts of these substances in the blood. $\mathrm{Nu}$ merous observations made on patients with fever showed no effect of changes in body temperature on the serum esterase value.

Fasting. The improvement in the clinical condition of Patient M. B. which was accompanied by corresponding changes in the serum esterase activity when large amounts of highly nutritious food were given suggested a study of the effects of fasting on the esterase activity. The effect of deprivation of all food except water on the serum esterase activity was studied in a dog fasted for 24 days. On the day preceding the fast the esterase activity was 2.13; on the eighth day of fast it was 2.19 , and on the twenty-fourth day the esterase activity was practically unchanged 


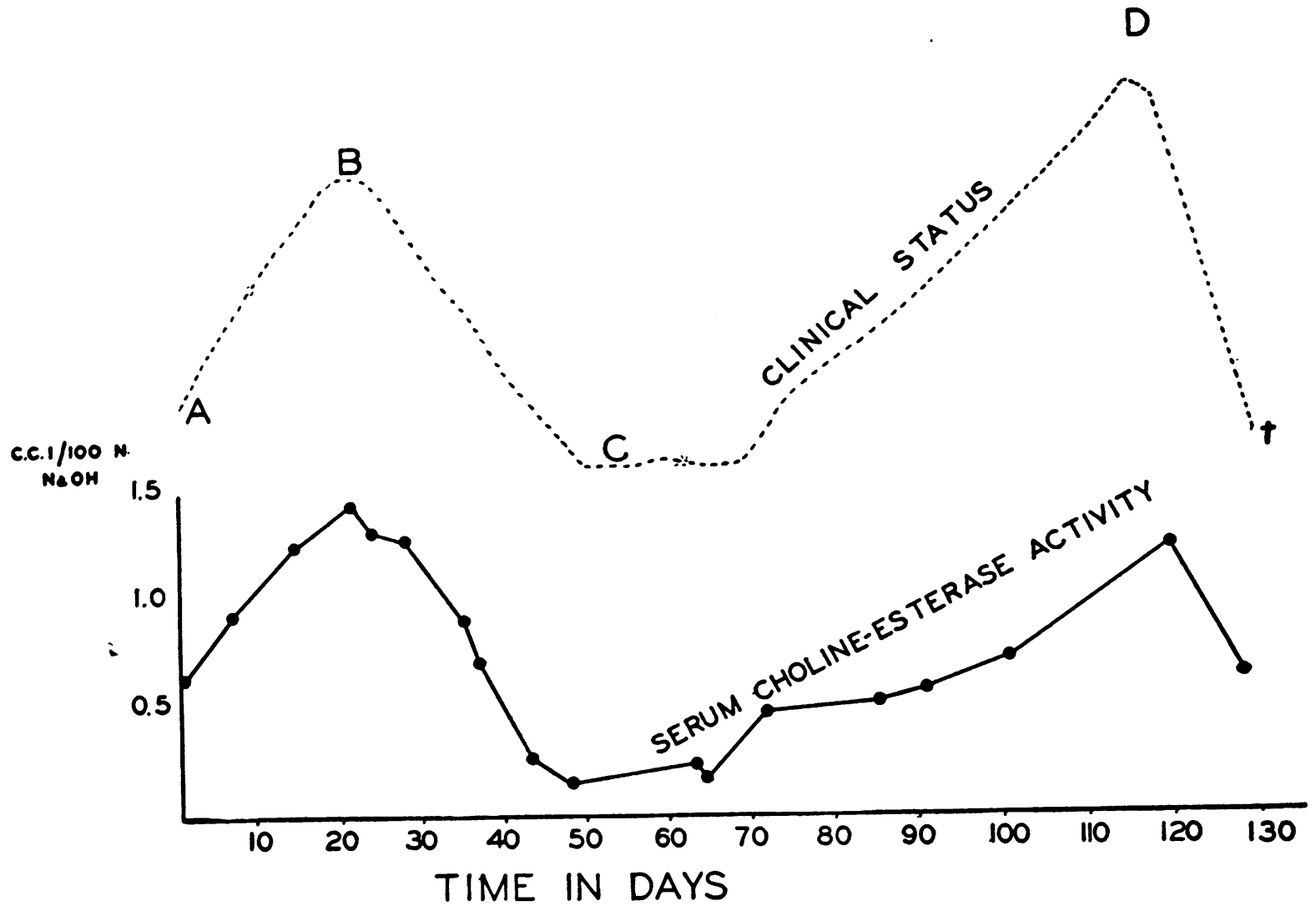

Fig. 3. Concomitant Changes in the Serum Esterase Activity and the Clinical Status of Patient S. S. With Pemphigus vulgaris

Patient at $\mathrm{A}$ was bedridden; at $\mathrm{B}$ he was able to walk about the ward; at $\mathrm{C}$ he was considerably debilitated, and comatose; at $\mathrm{D}$ he was again much improved; at $\dagger$ the patient died.

with a value of 2.34 . The animal showed no deleterious effects of the fast; its general condition was excellent although 27 per cent of the body weight was lost during the period of fasting.

Convulsions. The serum esterase activity in epilepsy was observed to be unchanged by a major seizure. The serum esterase activity of a girl aged 13 years with idiopathic epilepsy was determined two hours before a convulsion, during a major seizure, and five minutes after the attack. The esterase values were $3.13,3.13$, and 3.24 respectively.

\section{DISCUSSION}

The observations made in these studies are in agreement with those of Stedman, Stedman and Easson (6), Lucas, Hall, and Ettinger (5) and McGeorge (7), in that no correlation was found between the serum esterase activity and the clini- cal syndrome. Nor did factors such as the age, sex, or body weight of the patient appear to have any effect on the esterase values. In most subjects, including those with myasthenia gravis the esterase activity of the serum was constant over periods of weeks and even of several months. However, in patients with debilitation, very low esterase values were observed. In a few fatally ill patients with extreme debilitation the esterase activity of the serum was only about one-tenth to one-fifth that observed in normal subjects. These values are comparable with those seen in normal persons after the administration of large doses of physostigmine or prostigmin, in which instances the inhibition of the esterase activity is accompanied by considerable evidence of stimulation of cholinergic nerves. Since most of the patients who showed such low esterase values in this study were entirely free from such symptoms 
it is probable that acetylcholine was being produced in subnormal amounts at the nerve endings. The lack of symptoms would indicate an equilibrium between the rates of production and cleavage of the acetylcholine. This formulation assumes, of course, a relationship between the esterase activity in the serum and that at the nerve endings. While no direct evidence of this relationship is available at the present time, it appears highly probable that such a relationship exists. Whether the convulsions observed in one patient and the "myotonia" in another were related to a lowered rate of destruction of acetylcholine is not known. The data show that convulsions do not affect the esterase activity of the serum. Moreover, there is no evidence of an abnormal esterase value in idiopathic epilepsy. In a series of observations to be published later the effect of physostigmine and prostigmin on convulsions will be discussed.

Not all patients showing debilitation had low esterase values. On the other hand, all of the patients with very low esterase values showed considerable debilitation subsequent to some advanced and in most instances generalized toxic process. The patients in this group had a wide variety of clinical conditions, e.g., nephritis, leukemia, carcinoma, nutritional deficiency, ulcerative colitis, pemphigus vulgaris, and lupus erythematosus. In tuberculosis associated with cachexia Vahlquist (14) found very low esterase values. That low esterase values are not characteristic of these conditions is shown by the higher values of other patients in the earlier stages of these diseases. What factors in debilitation determine the lowered esterase activity (and presumably the lowered production of acetylcholine) are not known. It is likely that any serious toxic state can decrease the production and hydrolysis of acetylcholine and that these changes are important factors in determining the degree of debilitation. In contrast, patients seriously or even fatally ill with disease confined to one or a few organs but without generalized toxic manifestations showed only slight or moderate depression of the esterase activity. Most patients studied in this investigation showed relatively little change in their serum esterase values over periods of several weeks. On the other hand, some of the patients with debilitation showed considerable changes in the esterase activity of the serum concomitantly with changes in the clinical status. In two such patients the serum esterase values were of prognostic significance.

The serum esterase activity of the six patients with myasthenia gravis, in this series, was of the same order as that of most of the other patients without this condition. The serum esterase values showed only minor, and apparently insignificant variations from day to day over periods of several weeks. Furthermore, no correlation between the esterase value of the serum and the severity of the symptoms in myasthenia gravis could be established.

It is of interest that the serum esterase activity showed no apparent relationship to the total mass of voluntary muscle. Considerable reduction of the total muscular mass can take place without any change in the esterase activity of the serum, providing the patient is without a disease producing general debilitation.

The data on the serum esterase activity of patients with hyperthyroidism, epilepsy, and anxiety states are not sufficient to permit a discussion of the results of Antopol, Tuchman, and Schifrin (11) and of Tod and Jones (15). Antopol, Tuchman, and Schifrin observed high esterase values in patients with untreated hyperthyroidism. The few observations made in hyperthyroidism in these studies showed serum esterase values which were of about the same order as those in the other conditions investigated. Tod and Jones found a high esterase activity in patients with anxiety states and low values in patients in catatonic stupor or with epilepsy. The few determinations made in patients with epilepsy or with anxiety states in these studies showed no characteristic or unusual values in these conditions. The present investigations suggest that the general physical condition of the patients must be considered in the evaluation of any group of data on the esterase activity in disease. Furthermore, these studies indicate that the factor of debilitation is of more importance than is the nature of the clinical syndrome.

\section{SUM MARY}

The choline-esterase activity of the blood serum in a large group of diseases was found to be unrelated to the type of clinical syndrome or to factors such as age, sex, body weight, muscular 
mass, and body temperature. Convulsions and prolonged fasting were without effect on the serum esterase activity.

In myasthenia gravis and muscular wasting the esterase activity of the serum was normal.

The esterase activity differed widely among the subjects but was constant for periods of weeks in most subjects. However, in patients with debilitation the esterase level often was low (onefifth to one-tenth normal) and changed concomitantly with the clinical status of the patients.

\section{BIBLIOGRAPHY}

1. Dale, H. H., Feldberg, W. and Vogt, M., Release of acetylcholine at voluntary motor nerve endings. J. Physiol., 1936, 86, 353.

2. Brown, G. L., Dale, H. H., and Feldberg, W., Reactions of the normal mammalian muscle to acetylcholine and eserine. J. Physiol., 1936, 87, 394.

3. Walker, M. B., Treatment of myasthenia gravis with physostigmine. Lancet, 1934, 1, 1200.

4. Walker, M. B., Case showing the effect of prostigmin on myasthenia gravis. Proc. Roy. Soc. Med., 1934-35, 28, 759.

5. Lucas, C. C., Hall, G. E., and Ettinger, G. H.., Individual and species variations in the choline esterase and other esterases of blood serum. J. Pharmacol. and Exper. Therap., 1935, 54, 151.
6. Stedman, E., Stedman, E., and Easson, L. H., Choline-esterase. An enzyme present in the bloodserum of the horse. Biochem. J., 1932, 26, 2056.

7. McGeorge, M., Choline esterase activity in diseasewith special reference to myasthenia gravis. Lancet, 1937, 1, 69.

8. Hicks, C. S., Myasthenia gravis. Med. J. Australia, $1936,1,894$.

9. Stedman, E., and Russell, W. R., The choline-esterase content of blood in myasthenia gravis. Biochem. J., 1937, 31, 1987.

10. Stedman, E., Stedman, E., and White, A. C., A comparison of the choline-esterase activities of the blood-sera from various species. Biochem. J., 1933, 27, 1055.

11. Antopol, W., Tuchman, L., and Schifrin, A., Cholineesterase activity of human sera, with special reference to hyperthyroidism. Proc. Soc. Exper. Biol. and Med., 1937, 36, 46.

12. Shaffer, $P$., The excretion of kreatinin and kreatin in health and disease. Am. J. Physiol., 1908, 23, 1.

13. Milhorat, A. T., and Wolff, H. G., Studies in diseases of muscle. I. Metabolism of creatine and creatinine in progressive muscular dystrophy. Arch. Neurol. and Psychiat., 1937, 38, 992.

14. Vahlquist, B., On the esterase activity of human blood plasma. Skandinav. Arch. f. Physiol., 1935, 72, 133.

15. Tod, H., and Jones, M. S., A study of the choline esterase activity in nervous and mental disorders. Quart. J. Med., 1937, n.s. 6, 1. 